\title{
Analisis Faktor-Faktor yang Mempengaruhi Non Performing Financing (NPF) Pada Bank Pembiayaan Rakyat Syariah (BPRS) di Indonesia Tahun 2013-2018
}

\author{
Putri Perdani $^{1^{*}}$, Maskudi ${ }^{1}$ dan Risti Lia Sari ${ }^{2}$ \\ ${ }^{1}$ Jurusan Ekonomi Islam Fakultas Ekonomi Universitas Wahid Hasyim \\ ${ }^{2}$ Jurusan Manajemen Fakultas Ekonomi Universitas Wahid Hasyim \\ "Email: Putriperdani7@gmail.com
}

\begin{abstract}
Abstrak
Penelitian ini bertujuan untuk menganalisis faktor-faktor yang mempengaruhi Non Performing Financing (NPF) pada Bank Pembiayaan Rakyat Syariah (BPRS) di Indonesia. Adapun metode analisis data yang digunakan adalah Analisis Regresi Berganda dengan data time series dan menggunakan bantuan aplikasi SPSS Versi 16.0. Data penelitian terdiri dari Capital Adequacy Ratio (CAR), Financing to Deposit Ratio (FDR), Biaya Operasional Pendapatan Operasional (BOPO),Inflasi dan Non Performing Financing $(N P F)$. Hasil penelitian menunjuka bahwa Biaya Operasional Pendapatan Operasional (BOPO) berpengaruh positif dan signifikan terhadap Non Performing Financing (NPF) pada Bank Pembiayaan Rakyat Syariah (BPRS) di Indonesia. Sedangkan Capital Adequacy Ratio (CAR) dan Financing to Deposit Ratio (FDR) berpengaruh negatif dan signifikan Non Performing Financing (NPF). Variabel Inflasi tidak berpengaruh terhadap Non Performing Financing (NPF) pada Bank Pembiayaan Rakyat Syariah (BPRS) di Indonesia. Hasil penelitian menunjukan secara bersama-sama variabel CAR, FDR, BOPO dan Inflasi berpengaruh terhadap NPF pada BPRS di Indonesia. Capital Adequacy Ratio (CAR), Financing to Deposit Ratio (FDR), Biaya Operasional Pendapatan Operasional (BOPO) dan Inflasi memberikan pengaruh 72,6\% terhadap Non Performing Financing (NPF) pada Bank Pembiayaan Rakyat Syariah (BPRS) di Indonesia, dan 27,4\% sisanya dipengaruhi oleh variabel yang tidak masuk dalam penelitian ini.
\end{abstract}

Kata kunci : Non Performing Financing (NPF), Capital Adequacy Ratio (CAR), Financing to Deposit Ratio (FDR), Biaya Operasional Pendapatan Operasional (BOPO),Inflasi.

\section{PENDAHULUAN}

Perekonomian suatu negara yang semakin berkembang, akan meningkatkan kebutuhan pendanaan di suatu negara. Tidak semua pendanaan akan bersumber pada dana pemeintah atau APBN. Lembaga keuangan atau perbankan adalah salah satu yang berperan penting untuk proses pembiayaan atau pendanaan. Di Indonesia memiliki dua jenis perbankan yang beroperasi yaitu perbankan syariah dan konvensional. Dalam Undang - Undang No.21 Tahun 2008 tentang perbankan syariah bahwa bank syariah menurut jenisnya terdiri atas Bank Umum Syariah (BUS), Unit Usaha Syariah (UUS) dan Bank Pembiayaan Rakyat Syariah (BPRS). BPRS dipercaya masyarakat sebagai penyaluran dana berdasarkan untuk meningkatkan taraf hidup masyarakat yang bersifat produktif. Pembiayaan merupakan salah satu fungsi yang dilakukan oleh bank syariah, karena dengan adanya pembiayaan merupakan salah satu alternatif bank syariah untuk membantu masyarakat dalam menjalankan usahanya. Semakin tingginya pembiayaan maka semakin tinggi pula yang akan dihadapi BPRS dalam menghadapi risiko NPF. Pembiayaan merupakan salah satu kegiatan bank yang berhubungan langsung dengan sektor riil. Penyebab tingginya NPF ada beberapa faktor yaitu dari internal atau eksternal. Faktor internal yaitu CAR merupakan kecukupa modal yang dimiliki perbankan dalam menghadapai risiko seperti NPF, FDR merupakan rasio yang digunakan untuk mengukur likuiditas perbankan dalam pembiayaan yang diberikan, BOPO merupakan efektivitas dalam pengelolaan dana operasional perbankan. Selain itu faktor eksternal salah satunya adalah inflasi yaitu jika harga terus menerus naik menimbulkan dampak buruk kepada individu dan masyarakat, para penabung, kreditor atau debitor dan produsen. Berdasarkan uraian diatas, tujuan penelitian adalah analisis faktor-faktor yang menyebabkan Non Performing Financing (NPF) pada BPRS di Indonesia tahun 2013-2018.

Non Performing Financing (NPF) merupakan indikator pembiayaan bermasalah yang perlu diamati karena sifatnya yang tidak pasti sehingga penting untuk diamati. NPF merupakan instrumen penilaian kinerja sebuah bank syariah yang menjadi penilaian aktiva produktif hal ini 
diangkapan dalam penelitian Mares Suci Ana Popita (2013). Besaran rasio Non Performing Finance (NPF) atau Non Performing Loan (NPL) yang ditetapkan oleh BI Nomor 15/2/PBI/2013 adalah maksimal $5 \%$, maka akan mempengaruhi tingkat kesehatan bank yang bersangkutan. Modal merupakan yang sangat penting bagi perkembangan kegiatan usaha perbankan. Selain itu untuk kemajuan bank dan upaya untuk menjaga kepercayaan masyarakat. Bank Indonesia menetapkan mengenai ketentuan minimum modal, kecukupan modal serta menampung dalam risiko kerugian. Capital Adequacy Ratio merupakan kecukupan modal, menunjukan mempertahakan modal dan kemampuan bank dalam memanajemen, mengidentifikasi, mengukur, mengawasi dan mengontrol risiko yang timbul yang akan mempengaruhi bersarnya modal. Ketentuan batas CAR dari waktu ke waktu diubah oleh Bank Indonesia, antara lain : - Surat keputusan Direksi Bank Indonesia No. 26/20/KEP/DIR tanggal 29 Mei 1993, Bank Indonesia menetapkan CAR sebesar 8 \% dari Aktiva Tertimbang Menurut Ratio (ATMR). - Surat keputusan Direksi Bank Indonesia No.31/146/KEP/DIR tanggal 12 November 1998 menjadi $4 \%$ dari ATMR. Penurunan diakibatkan karena di Indonesia mengalami krisis moneter pada saat itu.

Tingkat kesehatan bank dapat dinilai dari beberapa indikator, salah satu indikator yang digunakan adalah laporan keuangan. Dari laporan terdapat beberapa rasio keuangan, yang salah satunya adalah rasio FDR, rasio ini merupakan rasio yang digunakan untuk mengukur likuiditas suatu bank dalam membayar kembali penarikan dana yang dilakukan oleh deposan. Rumus yang digunakan dari rasio Financing to Deposit Ratio (FDR) Rasio FDR bank syariah agar tidak menjadi terlalu rendah dan juga tidak terlalu tinggi, diperlukam standar mengenai tingkat FDR. Berdasarkan peraturan Bank Indonesia No. 15/7/PI 2013 tanggal 01 Desember 2013, besarnya Financing to Deposit Ratio (FDR) batasan berada pada tingkat $78 \%-110 \%$. Biaya Operasional Pendapatan Operasional (BOPO) Menurut Dahlan Siamat (2012) dalam jurnal Dedi Kusmayadi (2017), risiko operasional terjadi karena adanya ketidakpastian dalam usaha bank, adanya kerugian dari operasional pendapatan yaitu menurunnya tingkat keuntungan yang diperoleh dan terjadinya kegagalan atas jasa - jasa dan produk yang ditawarkan. Biaya operasional merupakan biaya yang dikeluarkan oleh perbankan untuk kegiatan operasional seperti dalam biaya gaji, biaya pemasaran, biaya bunga.

\section{METODE PENELITIAN}

Jenis penelitian yang digunakan adalah penelitian kuantitatif. Metode yang digunakan historis yaitu menganalisa suatu keadaan yang sudah lalu dan menganalisis hubungan antara variabel independen terhadap variabel dependen. Sedangkan populasi dan sampel yang digunakan adalah seluruh BPRS yang ada di Indonesia. Data yang digunakan dalam penelitian ini adalah data sekunder, yang berarti perolehan data dari dokumentasi, melalui laporan yang dipubilkasikan atau arsip - arsip resmi. Data sekunder dalam penelitian ini bersifat time series, yang berarti data yang digunakan adalah data bulanan atau pengumpulan data dari waktu ke waktu untuk melihat perkembangan. Perolehan data tersebut pada website Otoritas Jasa Keuangan (OJK) dan website Bank Indonesia (BI), dari tahun 2013 - 2018 dengan data bulanan. Metode analisis yang digunakan yaitu uji asumsi klasik yang terdiri dari uji normalitas, uji multikonearitas, heterokedastisitas dan autokorelasi. Selain itu menggunakan analisis regresi berganda dan juga uji signifikansi yang terdiri dari uji T, F dan determinasi (R2 ).

\section{HASIL DAN PEMBAHASAN}

Hasil penelitian menunjukan bahwa Capital Adequacy Ratio (CAR) berpengaruh negatif signifikan terhadap Non Performing Financing (NPF), jika suatu perbankan memiliki CAR yang tinggi akan mengurangi risiko NPF yang akan terjadi, karena kecukupan modal yang dimiliki dapat menampung risiko terjadinya NPF. Hasil penelitian menunjukan bahwa Financing to Deposit Ratio (FDR) berpengaruh negatif signifikan terhadap Non Performing Financing (NPF), bahwa dana pembiayaan yang disalurkan kepada nasabah dalam prinsip kehati-hatian sehingga timbulnya NPF sedikit ataupun berkurang. Hasil penelitian bahwa Biaya Operasional Pendapatan Operasional (BOPO) berpengaruh positif signifikan terhadap Non Performing Financing (NPF). Semakin kecil rasio BOPO berarti semakin efisien dalam kegiatan biaya operasional atau biaya yang dikeluarkan, maka semakin menurunnya rasio NPF. Hal ini dapat dikatakan dalam jumlah pembiayaan BPRS 
mendapatkan keuntungan yang maksimal karena efisiensi kegiatan operasional. Peningkatan pelayanan terhadap masyarakat dan kesehatan perbankan maka akan menurukan tingkat pembiayaan bermasalah. Hasil penelitian bahwa inflasi tidak berpengaruh terhadap Non Performing Financing (NPF). Terjadinya inflasi, dimana nasabah yang diberikan pembiayaan maka akan menimbulkan peningkatan keuntungan yang besar sehingga dalam proses pembayaran pembiayaan ke bank akan lancar dan rasio NPF akan berkurang.

Dari persamaan regresi terebut maka dapat diinterpretasikan sebagai berikut : 1. Nilai konstanta regresi sebesar 16,886. Menunjukan bahwa apabila Capital Adequacy Ratio (CAR), Financing to Deposit Ratio (FDR), Biaya Operasional Pendapatan Operasional (BOPO) dan Inflasi dengan kondisi konstan atau 0, maka Non Performing Financing (NPF) pada BPRS bernilai 16,886. 2. Koefisien Capital Adequacy Ratio (CAR) sebesar -0,449. Menunjukan bahwa CAR mempunyai pengaruh negatif terhadap NPF. Hal ini berarti bahwa apabila CAR meningkat satu satuan maka NPF akan menurun sebesar -0,449 dengan asumsi semua variabel independen lain konstan. 3. Koefisien Financing to Deposit Ratio (FDR) sebesar -0,061. Menunjukan bahwa FDR mempunyai pengaruh negatif terhadap NPF. Hal ini berarti bahwa apabila FDR meningkat satu satuan maka NPF akan menurun sebesar -0,061 dengan asumsi semua variabel independen lain konstan. 4. Koefisien Biaya Operasional Pendapatan Operasional (BOPO) sebesar 0,120. Menunjukan bahwa BOPO mempunyai pengaruh positif terhadap NPF. Hal ini berarti apabila BOPO meningkat satu satuan maka NPF akan meningkat sebesar 0,120 dengan asumsi semua variabel independen lain konstan. 5. Koefisien Inflasi sebesar -0,133. Menunjukan bahwa Inflasi mempunyai pengaruh negatif terhadap NPF. Hal ini berarti bahwa apabila Inflasi meningkat satu satuan maka NPF akan menurun sebesar - 0,133 dengan asumsi semua variabel independen lain konstan.

Hasil penelitian menunjukan bahwa Capital Adequacy Ratio (CAR) berpengaruh negatif signifikan terhadap Non Performing Financing (NPF), jika suatu perbankan memiliki CAR yang tinggi akan mengurangi risiko NPF yang akan terjadi, karena kecukupan modal yang dimiliki dapat menampung risiko terjadinya NPF. Hasil penelitian menunjukan bahwa Financing to Deposit Ratio (FDR) berpengaruh negatif signifikan terhadap Non Performing Financing (NPF), bahwa dana pembiayaan yang disalurkan kepada nasabah dalam prinsip kehati-hatian sehingga timbulnya NPF sedikit ataupun berkurang. Hasil penelitian bahwa Biaya Operasional Pendapatan Operasional (BOPO) berpengaruh positif signifikan terhadap Non Performing Financing (NPF). Semakin kecil rasio BOPO berarti semakin efisien dalam kegiatan biaya operasional atau biaya yang dikeluarkan, maka semakin menurunnya rasio NPF. Hal ini dapat dikatakan dalam jumlah pembiayaan BPRS mendapatkan keuntungan yang maksimal karena efisiensi kegiatan operasional. Peningkatan pelayanan terhadap masyarakat dan kesehatan perbankan maka akan menurukan tingkat pembiayaan bermasalah. Hasil penelitian bahwa inflasi tidak berpengaruh terhadap Non Performing Financing (NPF). Terjadinya inflasi, dimana nasabah yang diberikan pembiayaan maka akan menimbulkan peningkatan keuntungan yang besar sehingga dalam proses pembayaran pembiayaan ke bank akan lancar dan rasio NPF akan berkurang.

\section{KESIMPULAN}

Berdasarkan hasil penelitian dan pembahasan yang telah dipaparkan sebelumnya maka kesimpulan yang dapat diambil adalah sebagai berikut : 1 . Berdasarkan hasil pengujian dan pembahasan, Capital Adequacy Ratio (CAR) menunjukan pengaruh negatif signifikan terhadap Non Performing Financing (NPF) pada BPRS di Indonesia. Hal ini menunjukan bahwa semakin besar jumlah modal yang dimiliki suatu bank maka akan semakin kecil peluang terjadinya piutang Non Performing Financing (NPF). 2. Berdasarkan hasil pengujian dan pembahasan, Financing to Deposit Ratio (FDR) menunjukan pengaruh negatif dan signifikan terhadap Non Performing Financing (NPF) pada BPRS di Indonesia. Ketika variabel FDR mengalami peningkatan maka variabel NPF mengalami penurunan. 3. Berdasarkan hasil pegujian dan pembahasan bahwa Biaya Operasional Pendapatan Operasional (BOPO) menunjukan pengaruh positif dan signifikan terhadap Non Performing Financing (NPF) pada BPRS di Indonesia. Hal ini jika rasio BOPO tinggi maka kualitas pembiayaan berkurang sehingga akan meningkatkan rasio pembiayaan bermasalah atau NPF karena total pembiayaan berkurang. 4. Berdasarkan hasil penelitian dan pembahasan bahwa inflasi berpengaruh negatif tidak signifikan, yang artinya tidak berpengaruh terhadap Non Performing Financing (NPF) pada BPRS di Indonesia. 
Kenaikan inflasi dalam jangka panjang ketidaksignifikan NPF, karena bank syariah sebagai intermediasi bukan sebagai investasi seperti bank konvensional. 5. Berdasarkan hasil pengujian simultan bahwa Caiptal Adequacy Ratio (CAR), Financing to Deposit Ratio (FDR), Biaya Operasional Pendapatan Operasional (BOPO) dan Inflasi secara bersama - sama berpengaruh terhadap Non Performing Financing (NPF) pada BPRS di Indonesia. 6. Berdasarkan hasil uji determinasi menunjukan bahwa Caiptal Adequacy Ratio (CAR), Financing to Deposit Ratio (FDR), Biaya Operasional Pendapatan Operasional (BOPO) dan Inflasi memberikan kontribusi pengaruh terhadap Non Performing Financing (NPF) pada BPRS di Indonesia sebesar 72,6 \%. Sedangkan $27,4 \%$ sisanya dipengaruhi oleh variabel lain yang tidak dimasukan dalam penelitian.

\section{DAFTAR PUSTAKA}

Akbar, Dinnul Alfian, 2016, "Inflasi, Gross Domestic Product (GDP),Capital Adequacy Ratio(CAR) dan Financing to Deposit Ratio (FDR) terhadap NPF pada Bank Umum Syariah di Indonesia", UIN Raden Fatah Palembang. Jurnal Ekonomi Islam, Vol. 2, No. 2, Desember 2016.

Amin, Rukhul, Haqiqi Rafsanjani dan Abdul Mujib, 2017, "Faktor - Faktor yang Mempengaruhi Non Performing Financing Studi Kasus pada Bank dan BPR Syariah di Indonesia", Universitas Muhammadiyah Surabaya. Jurnal Ekonomi dan Perbankan Syariah, Vol. 2, No. 2, 2017.

Aqsa, Yanuar Nur, 2016, "Implementasi Prinsip Kehati - hatian dalam Pembiayaan Murabahah di BPRS Central Syariah Utama Surakarta", IAIN Surakarta.

Asnaini, Sri Wahyuni, 2014 "Faktor - Faktor yang Mempengaruhi Non Performing Financing (NPF) pada Bank Umum Syariah di Indonesia", Universitas Mercu Buana. Jurnal tekun, Vol. 5, No.2, September 2014.

Faiz, Ihda A, 2010, "Ketahanan Kredit Perbankan Syariah terhadap Krisis Keuangan Global". Jurnal Ekonomi Islam, Vol 4, No.2, Desember 2010. Firdaus, Rizal Nur, 2015, "Pengaruh Faktor Internal dan Eksternal yang Mempengaruhi Pembiayaan Bermasalah pada Bank Umum Syariah di Indonesia", Universitas Brawijaya. Jurnal, Vol. 3, No.1, Januari, 2015.

Firmansyah Arif, Jhon Fermos, 2018, "Analisis Kredit Bermasalah Dilihat dari Standar Non Performing Loan (NPL) pada PT BPR Prima Mulia Anugrah Cabang Padang", Akademi Keuangan dan Perbankan. Fimansyah, Irman, 2014, "Faktor Penyebab terjadinya Pembiayaan Bermasalah pada Bank Pembiayaan Rakyat

Syariah di Indonesia". Jurnal Ekonomi Bisnis, Vol. 8, No. 2, Juli 2014.

Haifa dan Dedi Wibowo, 2015, "Pengaruh Faktor Internal Bank dan Makro Ekonomi terhadap Non Performing Financing Perbankan Syariah di Indonesia Periode 2010 - 2014", Universitas Indonesia. Jurnal Nisbah, Vol. 1, No. 2, Desember 2015.

Hidayatullah, M Irsyad, 2017, " Pengaruh Variabel Internal Bank Terhadap Non Performing Financing pada BPRS di Indonesia periode 2010 - 2016", UIN Syarif Hidayatullah.

Ilyas, Rahmat, 2015, "Konsep Pembiayaan dalam Perbankan Syariah", STAIN Kudus. Jurnal Penelitian, Vol. 9, No. 1, Februari 2015.

Kusmayadi, Dedi, 2017, "Penilaian Kesehatan Bank Perkreditan Rakyat denganFaktor CAMEL", UNSIL. Jurnal Akuntansi, Vol. 12, No. 1, Januari - Juni 2017.

Lidyah, Rika, 2016, "Dampak Inflasi, BI Rate, Capital Adequacy Ratio (CAR), Biaya Operasional Pendapatan Operasional (BOPO) terhadap Non Performing Financing (NPF) pada Bank Umum Syariah di Indonesia", UIN Raden Fatah Palembang. Jurnal, Vol. 2 No. 1, Juli 2016.

Muhammad, 2019, "Determinants of Non Performing Financing (NPF) on Sharia Rural Bank (BPRS) in Indonesia", Universitas Negeri Semarang. Jurnal Ekonomi Vol. 2, No. 1, Januari 2019.

Musjtari, Dewi Nurul, 2012, "Penyelesaian Sengketa dalam Praktik Perbankan Syariah", Parama, Yogyakarta. Muslimin, Supriadi, 2012, "BPRShtt ps://www.slideshare.net/Supria diMuslimin/bprs, diunduh tanggal 17 April 2019

Mutamimah dan Siti Nur Chasanah, 2012, "Analisis Ekternal dan Internal dalam Menentukan Non Performing Financing Bank Umum Syariah di Indonesia", Unissula Semarang. Jurnal Bisnis dan Ekonomi, Vol. 19, No. 1, Maret 2012. 
Nurmuliyani, Ani, 2016, "Analisis Faktor - Faktor NPF pada BPRS di Indonesia Priode 2010 2015 ", UIN Syarif Hidayatullah.

Poetry, Zakiyah Dwi, 2011, "Pengaruh Variabel Makro dan Mikro terhadap NPL Perbankan Konvensional dan NPF Perbankan Syariah", STEI TAZKIA. Islamic Finance and Business Review, Vol 6 No. 2, 2011.

Popita, Mares Suci Ana, 2013, "Analisis Penyebab Terjadinya Non Performing Financing pada Bank Umum Syariah di Indonesia", Universitas Negeri Semarang. Jurnal Akuntansi, Vol. 2, No. 4, 2013.

Putra, Fary Adisetya, 2017, "Faktor Determinan Penyebab Non Performing Financing pada Bank Pembiayaan Rakyat Syariah di Indonesia periode 2008 -2015", Universitas Airlangga. Jurnal Ekonomi Syariah, Vol. 5 No. 4, April 2018.

Riannasari, Vikky, 2017, " Faktor - Faktor yang Mempengaruhi NPF (Non Performing Financing) Berdasarkan Golongan Pembiayaan pada BPRS di Indonesia", Universitas Islam Indonesia.

Santoso, Septiono Budi, Sudarto dan Bambang Sunarko, 2014, "Analisis Pengaruh LDR, BOPO, SIZE, LAR dan NIM terhadap NPL pada BPR Konvensional di Wilayah Jawa Tengah Periode 2010 - 2012", Universitas Jenderal Soedirman.

Shomad, Abd, Trisadani P. Usadani, 2011, "Transaksi Bank Syariah", PT Bumi Aksara, , Jakarta. Sugiyono, 2015, " Metode Penelitan Kuantitatif, Kualitatif dan R \& D ", CV ALFABETA, Bandung.

Vani, Kartika Marella dan Wahibur Rokhman "Analisis Faktor - Faktor yang Mempengaruhi Non Performing Financing pada Perbankan Syariah di Indonesia Tahun 2011-2016", Sekolah Tinggi Sgama Islam Negeri Kudus.Vol 5, No.2, 2017.

Wahyu, Didin Rasyidin, 2016, "Financing to Deposit Ratio sebagai salah satu Penilaian Kesehatan Bank Umum Syariah Studi Kasus pada Bank BJB Syariah Cabang Serang", IAIN Sultan Maulana Banten. Jurnal Ekonomi Keuangan dan Bisnis Islam, Vol. 7, No. 1, Januari - Juni 2016.

Yusuf, Muhammad, 2017, "Dampak Indikator Rasio Keuangan terhadap Profitabilitas Bank Umum Syariah di Indonesia", STIE Indonesia. Jurnal Keuangan dan Perbankan, Vol. 13, No. 2, Juni 2017. Laporan Statistika Perbankan Syariah Otoritas Jasa Keuangan Januari 2009 sampai Desember 2018 